
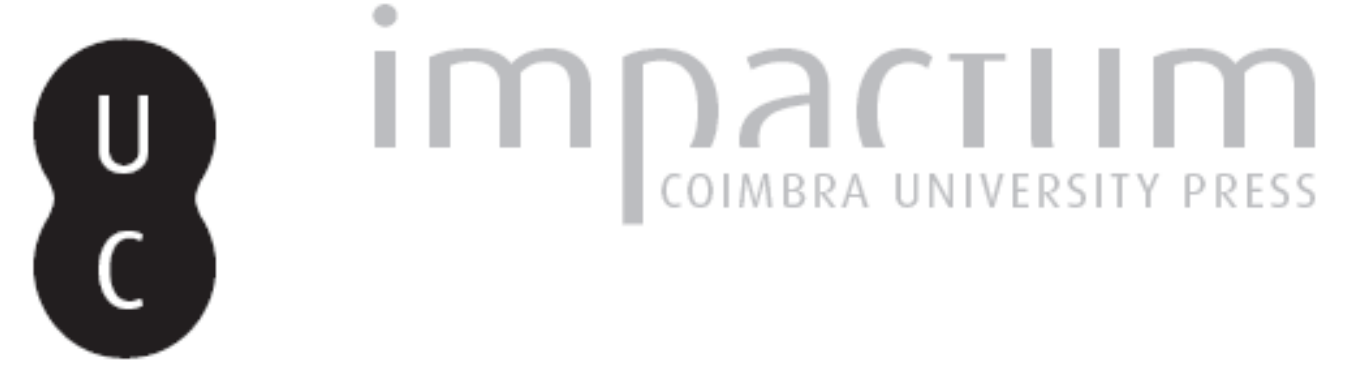

\title{
Vulnerabilidade à erosão costeira e riscos associados à ocupação: estudo de caso do município de Aracaju Sergipe, Brasil
}

\author{
Autor(es): $\quad$ Mota, Luana Santos Oliveira; Souza, Rosemeri Melo \\ Publicado por: Imprensa da Universidade de Coimbra \\ URL \\ persistente: \\ URI:http://hdl.handle.net/10316.2/43274 \\ DOI: \\ DOI:https://doi.org/10.14195/1647-7723_25-1_7 \\ Accessed : $\quad$ 26-Apr-2023 13:45:51
}

A navegação consulta e descarregamento dos títulos inseridos nas Bibliotecas Digitais UC Digitalis, UC Pombalina e UC Impactum, pressupõem a aceitação plena e sem reservas dos Termos e Condições de Uso destas Bibliotecas Digitais, disponíveis em https://digitalis.uc.pt/pt-pt/termos.

Conforme exposto nos referidos Termos e Condições de Uso, o descarregamento de títulos de acesso restrito requer uma licença válida de autorização devendo o utilizador aceder ao(s) documento(s) a partir de um endereço de IP da instituição detentora da supramencionada licença.

Ao utilizador é apenas permitido o descarregamento para uso pessoal, pelo que o emprego do(s) título(s) descarregado(s) para outro fim, designadamente comercial, carece de autorização do respetivo autor ou editor da obra.

Na medida em que todas as obras da UC Digitalis se encontram protegidas pelo Código do Direito de Autor e Direitos Conexos e demais legislação aplicável, toda a cópia, parcial ou total, deste documento, nos casos em que é legalmente admitida, deverá conter ou fazer-se acompanhar por este aviso.

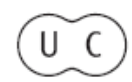


territorium/25w|.

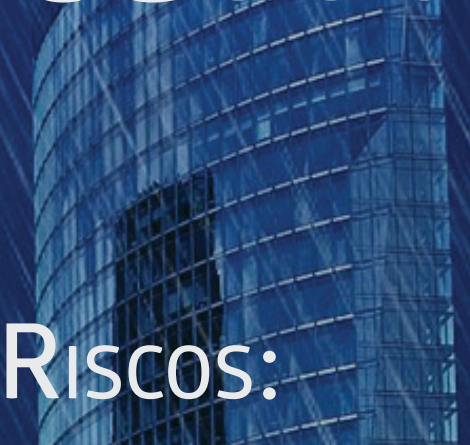

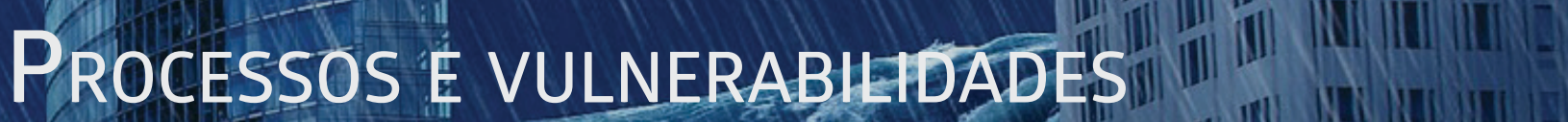

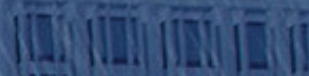
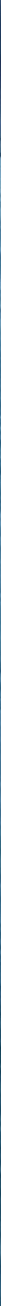

Imprensa da Universidade de Coimbra

Associação Portuguesa de Riscos, Prevenção e Segurança

2018 


\title{
VULNERABILIDADE À EROSÃO COSTEIRA E RISCOS ASSOCIADOS À OCUPAÇÃO: ESTUDO DE CASO DO MUNICÍPIO DE ARACAJU/SERGIPE, BRASIL*
}

\author{
VULNERABILITY TO COASTAL EROSION AND RISK RELATED TO OCCUPATION: A CASE STUDY - ARACAJU CITY, \\ STATE OF SERGIPE, BRAZIL
}

Luana Santos Oliveira Mota

Universidade Federal de Sergipe (Brasil) oliveiras.lua@gmail.com

Rosemeri Melo e Souza

Universidade Federal de Sergipe (Brasil) rome@ufs.br

\begin{abstract}
RESUMO
O presente trabalho tem por escopo a mensuração do risco associado à ocupação da frente litorânea do município de Aracaju/SE. Os procedimentos metodológicos adotados foram: a avaliação do comportamento da linha de costa em médio prazo, a análise dos geoindicadores de modificação da linha de costa em curto prazo, identificação do nível de ocupação e o mapeamento das áreas de risco. Os resultados indicaram que grande parte da área estudada está inserida nos graus médio e alto de risco, em razão da proximidade da ocupação da linha de costa associada ao comportamento do ambiente praial. A única área classificada como risco baixo encontra-se às margens da desembocadura do rio Vaza-Barris, que mesmo apresentando elevada variabilidade morfodinâmica, apresenta índices muito baixos de ocupação. A partir dos diferentes graus de risco delimitou-se as áreas de manejo especial, a fim de propor medidas de prevenção e mitigação de prejuízos econômicos associados à erosão costeira, tal como auxiliar no planejamento e ordenamento da ocupação.
\end{abstract}

Palavras-chave: Dinâmica costeira, linha de costa, geoindicadores, expansão urbana, áreas de manejo especial.

\section{ABSTRACT}

The goal of this case study is to measure the risk associated to the occupation of the coastal front of the Aracaju city, state of Sergipe. The following methodological procedures were adopted: the evaluation of coastline behaviour in the mid-term; analysis of shoreline modification geo-indicators in the short term; identification of the level of occupation and mapping of risk areas. The results indicated that a great part of the studied area is inside the medium and high degrees of risk. The reason is that occupation is close to the shoreline associated to beach environment behaviour. The only area classified as low risk was found in the mouth of the Vaza-Barris river banks. Although this area has high morphodynamic variability, it has very low occupancy rates. Based on the risk degree the areas of special management were delimited in order to propose measures for the prevention and mitigation of economic losses associated with coastal erosion and to assist in land occupation planning.

Keywords: Coastal dynamics, shoreline, geo-indicators, urban sprawl, special management areas.

\footnotetext{
* O texto deste artigo foi submetido em 19-07-2016, sujeito a revisão por pares a 02-09-2016 e aceite para publicação em 21-10-2016.

Este artigo é parte integrante da Revista Territorium, n. ${ }^{\circ} 25$ (I), 2018, ${ }^{\circ}$ RIscos, ISSN: 0872-8941.
} 
Introdução

O ambiente costeiro constitui uma das paisagens que apresenta maior complexidade diante da relação estabelecida entre os elementos físicos (continente, atmosfera e oceano) e antrópicos. Dentre os elementos físicos que modelam a paisagem costeira, destacam-se a ação das ondas, das correntes e dos ventos, cujas ações podem resultar na movimentação natural do posicionamento da linha de costa (R. Davis, D. Fitzgerald, 2004, M. Stive et al., 2002).

Não obstante a elevada fragilidade ambiental das zonas costeiras, são crescentes as taxas de ocupação da faixa litorânea, em função da uma grande valorização e exploração imobiliária da orla marítima. De acordo com E. Bird (2008, p. 01) “mais da metade da população mundial vive em regiões costeiras". Já no Brasil cerca de mais da metade da população vive a menos de $200 \mathrm{~km}$ do litoral (MINISTÉRIO DO MEIO AMBIENTE, 2002).

Com o modelo imediatista adotado pelo crescimento urbano associado à especulação imobiliária, principalmente nos ambientes costeiros, o planejamento para ocupação é realizado em curto prazo. Tal conjuntura não coincide com a escala temporal na qual ocorrem as mudanças promovidas pelos agentes naturais, especialmente na zona costeira. Assim, as diferentes formas de ocupação no referido ambiente, por vezes se contrapõem a dinâmica natural deste, fato que pode resultar tanto em prejuízos socioeconômicos como em impactos ao ambiente natural.

Partindo do princípio que o ambiente praial é extremamente dinâmico, regido por uma gama de agentes naturais, e em constante transformação, ganha ênfase no estudo da zona costeira, o processo de erosão. Tido como um fenômeno natural, a erosão costeira está intrínseca ao processo de movimentação natural da linha de costa, sendo considerado um perigo, quando da sua ocorrência em ambientes que possuam algum tipo de ocupação (R. Morton, et al., 1983).

De tal modo, a junção de um ambiente vulnerável a diversos eventos de ordem natural, a exemplo da erosão costeira, associado ao crescente processo de intervenção antrópica pode ocasionar o aparecimento de riscos, no caso de confluência entre elevada vulnerabilidade e altas taxas de ocupação. Dentro desse contexto, destaca-se o município de Aracaju/ $\mathrm{SE}$, que nas últimas décadas vem apresentando uma intensificação no processo de ocupação da sua frente litorânea. Além da destruição das unidades naturais, destaca-se a ocorrência de processos erosivos na linha de costa em alguns setores do município, que culminaram na destruição de estruturas antrópicas nas proximidades das desembocaduras do rio Sergipe e rio Vaza-Barris.
Ante o exposto, a presente pesquisa tem por objetivo classificar a frente litorânea de Aracaju/SE de acordo com os diferentes graus de vulnerabilidade à erosão costeira, associado à identificação dos diferentes níveis de ocupação, a fim de delimitar as áreas que apresentam riscos. Com base em tais dados e a partir dos preceitos do gerenciamento costeiro, propõe-se a delimitação da costa em áreas de manejo especial. Destarte, os resultados desta pesquisa poderão subsidiar o planejamento urbano e ambiental no que concerne à estruturação da ocupação na área estudada, evitando ou minimizando danos ambientais e prejuízos socioeconômicos.

\section{Área de Estudo}

A área investigada compreende a frente litorânea do município de Aracaju, localizada no litoral central do estado de Sergipe, delimitada ao Norte pela desembocadura do rio Sergipe e ao Sul pela desembocadura do rio Vaza-Barris (fig. 1). A referida área abarca as praias dos Artistas, da Atalaia Velha, da Aruana, do Robalo, do Refúgio, dos Náufragos e do Mosqueiro.

O clima do município de Aracaju é do tipo tropical úmido, com temperatura média anual de $28^{\circ} \mathrm{C}$ e precipitação pluviométrica média anual de $1.200 \mathrm{~mm}$. Segundo dados do INMET - Instituto Nacional de Meteorologia, colhidos para os de 2006 a 2015, o período de maior concentração

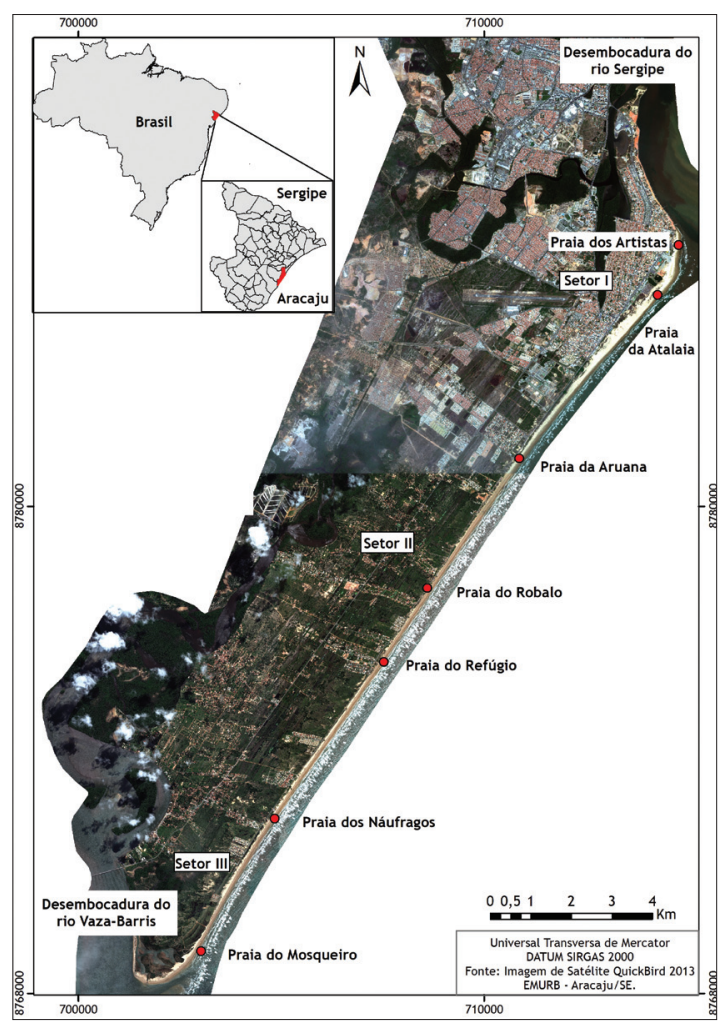

Fig. 1 - Localização da área de estudo.

Fig. 1 - Location of the study area. 
pluviométrica para o município ocorre entre os meses de Março e Agosto, sendo Maio o mês mais chuvoso.

0 regime de marés da região é do tipo meso-maré de caráter semi-diurno, com amplitude máxima de 2,0m e mínima de $-0,1 \mathrm{~m}$. As maiores amplitudes ocorrem nas marés de sizígia, principalmente nos meses de março, abril, agosto, setembro e outubro (DIRETORIA DE HIDROGRAFIA E NAVEGAÇÃO, 2015).

De acordo com o modelo de ondas elaborado por C. Pianca et al. (2010) e por M. Oliveira (2003), para o setor que compreende esta porção do litoral de Sergipe, detectou-se que as ondas incidentes são geradas pela ação dos ventos alísios, possuindo a predominância de $\mathrm{E}$ e secundariamente de SE. As ondas são reforçadas durante o inverno por ondas de S e SSE, associadas ao avanço das frentes polares, com o aumento na altura das ondas, que podem chegar a $3 \mathrm{~m}$ ou $4 \mathrm{~m}$ de altura (C. Pianca et al., 2010).

No que se refere à deriva litorânea, como a orientação da linha de costa de Sergipe é de NE-SW, e a direção que predomina na incidência de ondas é de $E$, a corrente de deriva litorânea, e consequentemente, o sentido do transporte de sedimentos é predominantemente de NESW (M. Oliveira, 2003).

\section{Procedimentos Metodológicos}

Para a operacionalização dos objetivos apontados, o presente trabalho foi conduzido em cinco etapas descritas nos itens a seguir.

Avaliação do comportamento da linha de costa em médio prazo

O posicionamento da linha de costa para médio prazo foi obtido a partir do mapeamento multitemporal para os anos de 1965, 1971, 1978, 1986, 2003, 2008, 2010 e 2014. Para tal, foi utilizado como indicador a linha de preamar máxima, a qual é identificada nas imagens aéreas como o limite entre a areia seca e areia molhada ( $\mathrm{S}$. Esteves, 2003). Ressalta-se que, a despeito das ressalvas existentes quanto ao referido indicador, este foi adotado tendo em vista os seguintes fatores: a morfodinâmica da praia, que apresenta características dissipativas; e o uso de uma série multitemporal de imagens que, de acordo com D. Muehe, L. Klumb-Oliveira (2014), reduz notadamente possíveis erros de intepretação.

Os mapas foram confeccionados sobre uma base cartográfica composta por fotografias aéreas de 1965, 1971, 1978, 1986 e 2004, ortofotos de 2004 e, imagens de satélite QuickBird de 2003, 2008, 2010 e 2014. As fotografias aéreas foram georeferenciadas com auxílio do programa GLOBAL MAPPER 15, tomando por base as ortofotos de 2004. Foi utilizado o sistema de projeção UTM e o datum SIRGAS BRASIL 2000 para o georreferenciamento e confecção dos mapas. Esta base cartográfica e os programas de geoprocessamento também foram utilizados na construção dos mapas associados às etapas metodológicas seguintes.

Análise dos geoindicadores de modificação da linha de costa e do nível de ocupação

Com o intuito de identificar os geoindicadores de modificação da linha de costa e analisar o nível de ocupação nas suas proximidades foram realizadas visitas a campo.

As principais características da praia e da linha de costa foram identificadas com base na metodologia exposta pelos autores D. Bush et al. (1999) e C. Souza e K. Suguio (2003). Estas consistem na identificação dos indícios de erosão, estabilidade e progradação da linha de costa e do nível de ocupação nas suas proximidades. Para a análise do comportamento da linha de costa foram considerados os seguintes geoindicadores (E. Bird, 2008, D. Bush et al., 1999, C. Souza, K. Suguio, 2003):

- Erosão - ausência de vegetação; estruturas artificiais na linha de costa e na praia; ausência de dunas, com frequência de sobrelavagem (overwash); dunas escarpadas; vegetação efêmera ou escassa ao longo da linha da escarpa;

- Estabilidade - escarpas inativas, desenvolvimento recente de vegetação, início da formação de feições deposicionais;

- Progradação - presença de feições deposicionais como bermas e terraços de praia, desenvolvimento de dunas frontais e pós-praia vegetada.

Para a área de estudo foram demarcados 25 pontos, com auxilio do GPS (global positioning system), com o propósito de observar o estado da praia. A distância entre os pontos foi de aproximadamente $1 \mathrm{~km}$, ocorrendo marcações entre estes quando ocorriam mudanças nas condições morfológicas da praia.

No que se refere ao nível de ocupação foram considerados as estruturas erguidas sobre a pós-praia e nas proximidades da linha de costa $(1 \mathrm{~km}$ em direção ao interior do continente). Para a diferenciação entre os níveis de ocupação foi analisada a posição e a distância em relação à linha de costa (perpendicularmente), juntamente a densidade da ocupação (paralelamente). A posição da ocupação foi identificada como muito próxima, próxima e distante; já para a densidade considera-se os níveis de ocupação: baixo (0-35\%), médio $(36-70 \%)$ e alto $(>70 \%)$. Vale ressaltar que os parâmetros seguidos para determinação dos valores baixo, médio e alto foram estabelecidos com base na comparação dos níveis de ocupação da própria área de estudo. 
Classificação da frente litorânea de acordo com os indicadores de vulnerabilidade à erosão costeira

A vulnerabilidade depende do grau de exposição de um ambiente ao impacto de determinado perigo e de como este pode absorver os impactos e se recuperar. Neste sentido, a vulnerabilidade natural da zona costeira decorre de dois fatores: exposição da linha de costa e dos ecossistemas costeiros aos perigos relacionados à dinâmica física do litoral, e da capacidade da linha de costa e dos ecossistemas costeiros de resistir, se recuperar (grau de resiliência) ou se adaptar. Com bases nesses preceitos foi mensurada a vulnerabilidade física à erosão costeira, embasado na metodologia exposta pelos autores F. Lins-de-Barros (2005) e I. Silva et al. (2007). Os seguintes indicadores foram analisados conjuntamente:

- Geoindicadores de modificação da linha de costa em curto prazo - análise dos setores a partir de indicadores de erosão, estabilidade ou progradação;

- Grau de exposição da praia - análise do quanto à praia está sujeita a ação efetiva das ondas, em função da presença de ilhas ou promontórios;

- Grau de resistência/resiliência da praia - identificado a partir da análise da cobertura vegetal no topo do perfil, associado à presença/ausência de dunas frontais e granulometria das praias.

- Tendência em médio prazo das variações da linha de costa - análise dos setores a partir das tendências verificadas para os últimos 50 anos.

Para fins de mensuração do grau de vulnerabilidade na TABELA I é apontado a discriminação dos valores utilizados no cálculo final.

Ressalta-se alguns pontos dentro da mensuração:

- O grau de exposição foi retirado do cálculo, apesar de compor um importante indicador, uma vez que toda a costa estudada apresenta grau de exposição elevado.

- Não foi considerado a granulometria, em função de os sedimentos nessas áreas serem de granulometria de fina a muito fina, não havendo grandes variações ao longo da costa.

- O grau de vulnerabilidade muito alta foi atribuído as áreas contiguas às desembocaduras fluviais, em função da elevada dinamicidade destes setores. Assim, independente do valor final atribuído, tais áreas sempre estarão contidas nesta classificação.

Identificação das áreas de riscos

As áreas de risco foram delimitadas com base nos índices de vulnerabilidade física à erosão costeira, associado ao nível e à distribuição da ocupação em relação à linha de costa (TABELA II). Não obstante, a existência do risco está atrelada primordialmente à ação humana, para fins de mensuração atribuiu-se o mesmo peso as duas variáveis, tendo em vista que as características biofísicas do ambiente costeiro contribuírem sobremaneira para potencialização dos riscos. Delimitação das áreas de manejo especial

A partir dos geoindicadores da modificação da linha de costa e da configuração atual da ocupação, foram analisadas as áreas próximas à linha de costa que necessitam de políticas de manejo específicas, com base na classificação realizada por S. Esteves (2003, p. 66):

- Áreas críticas - São áreas que requerem medidas de gerenciamento costeiro corretivo. Apresentam alto índice e/ou crescente ocupação, tendência à erosão e/ou destruição de estruturas costeiras durante eventos de alta energia, deslocamento da linha de costa, dunas primárias ausentes ou muito alteradas.

- Áreas de ação prioritária - São áreas sob pressão crescente, em que urge a aplicação de medidas de gerenciamento preventivo. Apresentam nível de ocupação moderado ou baixo, altas taxas de crescimento populacional, recente intensificação do uso (turismo, valorização imobiliária, conflitos de interesses), tendência à estabilidade ou erosão a curto ou longo-prazo.

- Áreas latentes - São áreas que atualmente não se encontram sob grande pressão de uso, mas que num futuro próximo podem se tornar áreas de ação prioritária, portanto é aconselhável a implementação de medidas reguladoras de ocupação e uso. Apresentam sistema praia/duna preservado ou pouco alterado, nível de ocupação moderado a baixo, e tendência à erosão ou estabilidade/acresção. Em geral, ocorrem nas proximidades de áreas críticas ou prioritárias, ou são áreas não urbanizadas que recentemente tiveram vias de acesso ampliadas ou criadas.

- Áreas naturais - São as áreas que têm suas características naturais preservadas, não são urbanizadas, apresentam pouca pressão de uso e sem indícios de que essas condições serão alteradas em um futuro próximo. Podem apresentar tendência à erosão, estabilidade ou acresção.

Destaca-se que tais classificações foram adaptadas às características encontradas na área de estudo.

\section{Resultados e Discussões}

Evolução da linha de costa em médio prazo da frente litorânea de Aracaju

As linhas de costa obtidas para os diferentes anos foram sobrepostas, em que foi possível visualizar as modificações do seu posicionamento para os últimos 50 anos (fig. 2). Em função das diferentes tendências 
TABELA I - Mensuração da vulnerabilidade física à erosão costeira.

TABLE I - Measurement of physical vulnerability to coastal erosion.

\begin{tabular}{|c|c|c|c|}
\hline $\begin{array}{c}\text { Grau de resistência } \\
\text { (A) }\end{array}$ & \multirow{2}{*}{$\begin{array}{l}\text { Tendência da linha de } \\
\text { costa em médio prazo (B) }\end{array}$} & \multirow{2}{*}{$\begin{array}{l}\text { Tendência da linha de } \\
\text { costa em curto prazo (C) }\end{array}$} & \multirow{2}{*}{ Vulnerabilidade física à erosão costeira } \\
\hline $\begin{array}{c}\text { Cobertura vegetal / } \\
\text { Dunas Frontais }\end{array}$ & & & \\
\hline $\begin{array}{l}\text { (1) Elevado } \\
\text { (2) Médio } \\
\text { (3) Baixo }\end{array}$ & $\begin{array}{l}\text { (1) Progradação } \\
\text { (2) Estabilidade } \\
\text { (3) Erosão }\end{array}$ & $\begin{array}{l}\text { (1) Progradação } \\
\text { (2) Estabilidade } \\
\text { (3) Erosão }\end{array}$ & $\begin{array}{l}\text { 1 - 1,4: Vulnerabilidade Baixa } \\
\text { 1,5 - 1,9: Vulnerabilidade Média } \\
\text { 2,0 - 2,4: Vulnerabilidade Alta } \\
\text { 2,5 - 3: Vulnerabilidade Muito Alta* } \\
\text { *Também atribuída às áreas contíguas às } \\
\text { desembocaduras fluviais, independente dos } \\
\text { valores obtidos. }\end{array}$ \\
\hline \multicolumn{4}{|c|}{$V_{\text {erosão costeira }}=(A+B+C) / 3$} \\
\hline
\end{tabular}

TABELA II - Mensuração do risco associado à ocupação nas proximidades da linha de costa.

TABLE II - Risk measurement associated to the occupation nearby the shoreline.

\begin{tabular}{|c|c|c|}
\hline Vulnerabilidade física à erosão costeira (A) & Nível e distribuição da ocupação (B) & Risco \\
\hline $\begin{array}{l}1 \text { - 1,4: Vulnerabilidade Baixa } \\
\text { 1,5 - 1,9: Vulnerabilidade Média } \\
\text { 2,0 - 2,4: Vulnerabilidade Alta } \\
\text { 2,5 - 3: Vulnerabilidade Muito Alta* } \\
\text { *Também atribuída às áreas contíguas às desem- } \\
\text { bocaduras, independente dos valores obtidos. }\end{array}$ & $\begin{array}{l}0 \text { - Ocupação inexistente } \\
0,1 \text { - 1: Baixo índice de ocupação } \\
1,1 \text { - 2: Médio índice de ocupação } \\
2,1 \text { - 3: Alto índice de ocupação }\end{array}$ & $\begin{array}{l}0 \text { - 1: Risco baixo } \\
\text { 1,1 - 2: Risco médio } \\
\text { 2,1 - 3: Risco alto }\end{array}$ \\
\hline
\end{tabular}

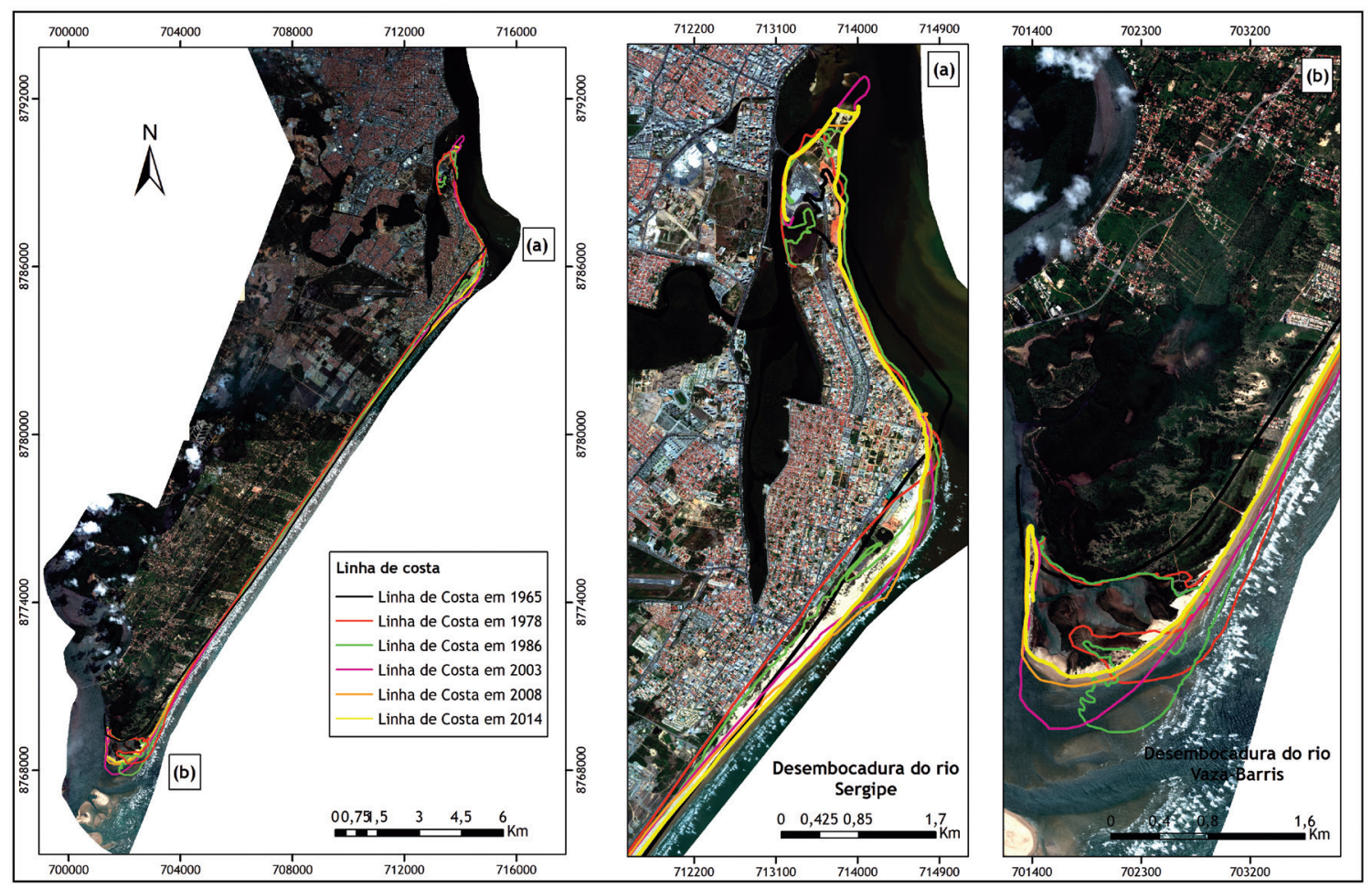

Fig. 2 - Variações no posicionamento da linha de costa entre 1965 e 2014.

Fig. 2 - Variation of the coastline positioning between 1965 and 2014. 
observadas, a área foi dividida em três setores: Setor I - localizada nas adjacências da margem direita da desembocadura do rio Sergipe; Setor II - compreende a porção central da área estudada e; Setor III - compreende as adjacências da margem esquerda da desembocadura do rio Vaza-Barris (vide fig. 1).

No setor 1, na porção localizada mais ao norte da área investigada, na praia dos Artistas e na praia da Atalaia, identificou-se comportamento de elevada variabilidade, com ciclos de erosão e sedimentação, e comportamentos diferenciados entre as referidas praias. A praia dos Artistas, nas vizinhanças da desembocadura, em médio prazo apresentou tendência à erosão, fato que resultou na construção de estruturas de contenção a fim de estabilizar a linha de costa. Já a praia de Atalaia evidenciou-se tendência geral à progradação, com episódios de erosão em curto prazo.

No setor II da área de estudo, observou-se a ocorrência de pequenas variações sazonais no posicionamento da linha de costa, com alternância entre períodos de erosão e progradação, o que caracteriza a estabilidade em médio prazo deste setor.

Já no setor III, localizado nas vizinhanças da margem esquerda do rio Vaza-Barris, na praia do Mosqueiro, foram identificadas grandes variações no posicionamento da linha de costa, tal como verificado no setor I. Houve progradação da linha de costa entre 1965 e 1986, e subsequente inversão de comportamento, com erosão da linha de costa entre 1986 e 2014. Vale ressaltar que, mesmo com a tendência à erosão verificada para os últimos 20 anos, a linha de costa atual, 2014, ainda encontra-se progradada em relação à de 1965 .

Os dados obtidos das análises da variação do posicionamento da linha de costa revelam que as áreas que mais estiveram sujeitas a eventos de erosão e sedimentação foram os setores adjacentes às desembocaduras. As áreas que intermedeiam os dois estuários mantiveram-se relativamente estáveis com episódios erosivos e de acresção em menores proporções. Tal característica corrobora os estudos de autores como R. Angulo (1993), A. Bittencourt et al. (2001), J. Cooper (2002), S. Esteves (2003), L. Wright (1977) e D. FitzGerald (1982) os quais definiram que as áreas que sofrem influência da dinâmica fluvial, tendem a ser altamente instáveis e apresentar elevada variabilidade devido à ação conjunta entre dinâmica fluvial e marinha.

Diante do estudo da vulnerabilidade física à erosão costeira, levando em consideração a elevada variabilidade morfodinâmica em médio prazo, considerou-se as áreas próximas as desembocaduras dos rios Sergipe e Vaza-Barris, com elevada vulnerabilidade física. Tal comprovação tem por pressuposto uma análise histórica que revela que ambas as áreas já estiveram submetidas a eventos erosivos de grandes proporções.
Análise da linha de costa em curto prazo

A frente litorânea de Aracaju foi analisada segundo os geoindicadores de modificação da linha de costa, que representam as características atuais e permitem a classificação da praia com base nas tendências à progradação, à estabilidade e à erosão. Para tanto, a linha de costa da área investigada, que compreende cerca de $24 \mathrm{~km}$, foi subdivida em 25 pontos de análise. Tais pontos apresentaram equidistâncias de aproximadamente $1 \mathrm{~km}$. Nestes setores foram analisados os geoindicadores, nível de ocupação, processos atuantes, entre outras características.

O setor I, que compreende os bairros da Coroa do Meio e Atalaia apresentou duas tendências diferenciadas. Verificou-se processo de progradação contínuo em quase toda sua extensão, onde foi visualizada vegetação bem desenvolvida, a presença de algumas dunas frontais, póspraia larga e vegetada com mais de $100 \mathrm{~m}$ de comprimento em alguns pontos e presença de bermas. A exceção deste setor refere-se às adjacências da desembocadura do rio Sergipe, que se apresenta com características de praias em erosão (escarpas ativas, estruturas artificiais de contenção e faixa de praia ausente durante a maré alta).

Ainda dentro do Setor I, vale destacar processo erosivo severo ocorrido entre os anos de 2007 e 2008, o qual culminou na destruição parcial de uma praça de eventos, além de bares e restaurantes. Observou-se a modificação da tendência da linha de costa, que se encontrava em processo de recuo, passando a figurar como estável com o cessar do processo erosivo, e, atualmente, apresentando tendência à estabilidade (fig. 3).

No setor II, que compreende as Praias da Aruana, Robalo, Refúgio e Náufragos verificou-se tendência à estabilidade em todos os setores. Identificaram-se também evidências de processos erosivos pretéritos que resultaram no retrabalhamento de feições deposicionais, eólicas e marinhas, que deram origem a escarpas de praia, encontradas na maioria dos pontos analisados. Atualmente estas escarpas estão inativas, caracterizando a estabilidade da praia. Soma-se a este indício de estabilidade, a presença de vegetação esparsa sobre algumas escarpas e sobre a própria praia.

No setor III, nas adjacências da desembocadura do rio Vaza-Barris, que compreende a praia do Mosqueiro, foi identificado tendência preponderante à erosão, com poucos setores com indícios de estabilidade.

Com base nos dados expostos, notou-se que em curto prazo comportamentos diferenciados foram notados entre os setores (fig. 4), que em muito se assemelharam ao comportamento da linha de costa em médio prazo.

No que concerne ao grau de exposição da frente litorânea de Aracaju, constatou-se que ao longo de toda a costa as praias são expostas a ação das ondas, em função da 
não existência de promontórios e ilhas. A única exceção está nas proximidades da margem esquerda do rio VazaBarris, onde em determinados períodos bancos arenosos aparecem e protegem a costa da ação direta das ondas, tornado este setor menos exposto.

Já os graus de resistência e resiliência das praias são definidos, respectivamente, em razão da capacidade do ambiente praial tem de conter processos erosivos e, no caso de ocorrência do referido fenômeno, a capacidade do ambiente de recuperar-se. Praias que possuem póspraia larga e com vegetação bem desenvolvida, feições deposicionais como dunas frontais e bermas, juntamente a presença de cobertura vegetal no topo do perfil, tendem a possuir maior grau de resistência e resiliência.

Atenção especial neste caso dá-se ao papel das dunas frontais. Em grande parte da extensão analisada são encontradas dunas frontais vegetadas de diferentes portes. As referidas feições auxiliam na manutenção do equilíbrio do sistema praial, uma vez que servem de reserva de sedimentos para a praia (N. Psuty, 2004, E. Bird, 2008), constituindose como um dos principais indicadores para o estudo da vulnerabilidade à erosão costeira.

A partir do momento que estas feições são destruídas ou interrompidas por estruturas artificiais, pode haver comprometimento na troca bidirecional de sedimentos. Este fato implica diretamente na dinâmica praial, uma vez que a praia perde uma de suas principais fontes de alimentação, fato que pode acarretar na ocorrência de processos erosivos (N. Psuty, 2004).

Para o caso da área de estudo, no setor II e III, as dunas frontais foram interrompidas pela construção da rodovia José Sarney (fig. 5-a). Já no setor I, algumas dunas foram suprimidas, em função da construção de aparatos turísticos, não obstante grande parte delas ainda esteja presente (fig. 5-b).

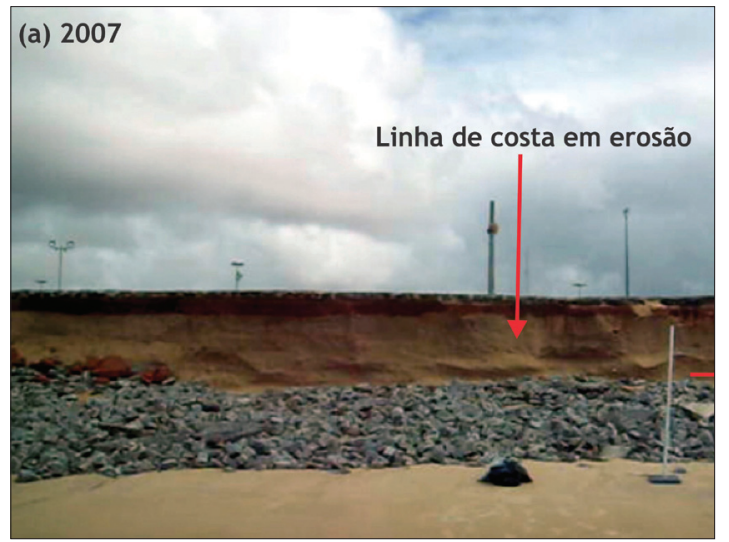

Observou-se também que nas áreas onde as dunas frontais são mais presentes, os processos erosivos ocorrem, no entanto, a praia tem maior capacidade de se recuperar destes eventos devido ao fornecimento de sedimentos pelas dunas (fig. 6-b). Estas feições ainda constituem uma barreira natural no que se refere às ocupações que ficam na retaguarda destas. Nas áreas em que as dunas foram destruídas ou tiveram a dimensão reduzida, o

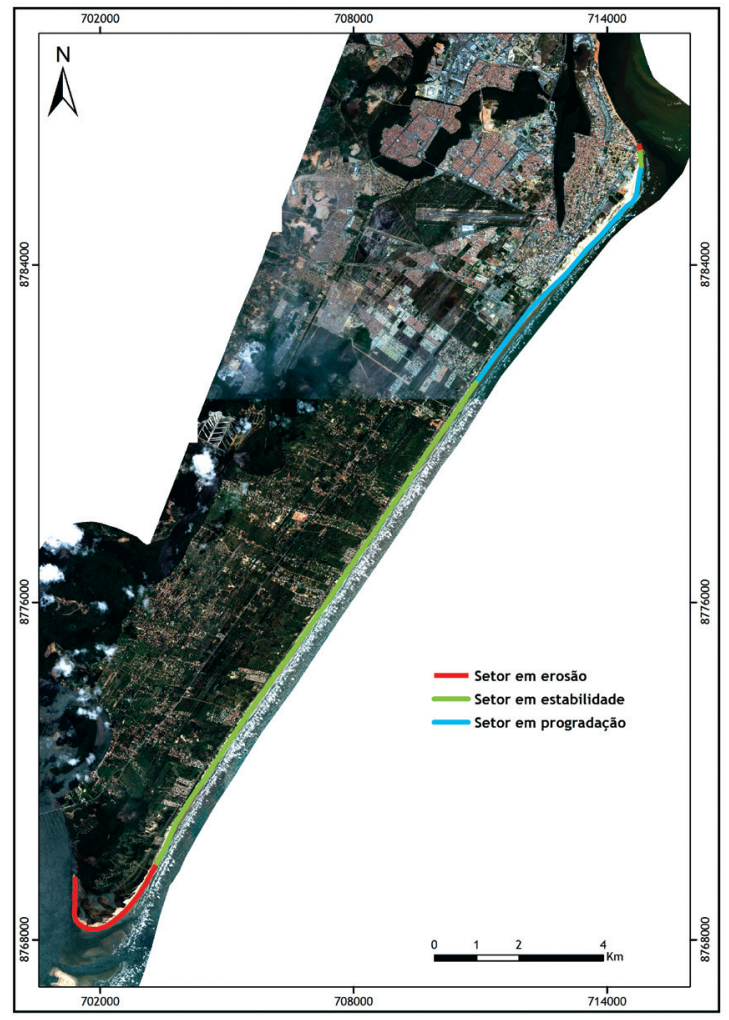

Fig. 4 - Tendências observadas para linha de Aracaju em curto prazo a partir dos geoindicadores.

Fig. 4 - Trends of Aracaju's shoreline observed in the short-term from geo-indicators.

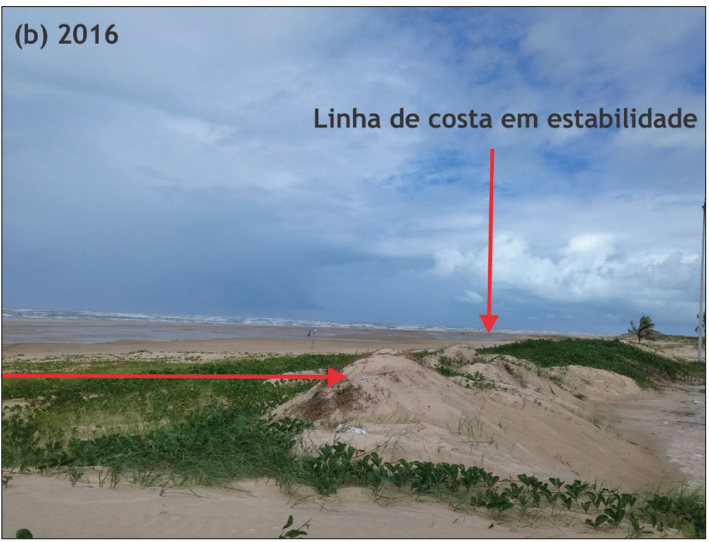

Fig. 3 - Modificação na tendência da linha de costa na praia de Atalaia entre 2007 e 2016 (Fonte: Luana Santos Oliveira Mota, (a) agosto de 2007; (b) setembro de 2016).

Fig. 3 - Variation of the coast line tendency in Atalaia beach between 2007 and 2016 (Source: Luana Santos Oliveira Mota, (a) August 2007; (b) September 2016). 
processo de recuperação da praia pode ser mais lento e, ainda que a praia encontre-se em estabilidade, fenômenos erosivos futuros podem atingir as estruturas fixas (fig. 6-a) (N. Psuty, 2004).

Vulnerabilidade física à erosão costeira da frente litorânea de Aracaju/SE.

Como já foi estabelecido anteriormente, o estudo da vulnerabilidade física à erosão costeira envolve a junção de diversos indicadores que pressupõe o estado da praia. Como grande parte dos dados analisados pelos autores utilizados como referencial teórico-metodológico perfazem a escala temporal de curto prazo, optou-se por incluir dados de médio prazo, referentes às variações da linha de costa, no processo de mensuração da vulnerabilidade física. Isto porque parte-se do pressuposto que o ambiente costeiro está sujeito a grandes modificações e apresenta elevada dinamicidade em função dos diversos agentes atuantes. Por conseguinte, entende-se que estudos presos a análises de curto prazo podem não dar suporte adequado ao planejamento para estas áreas, em função do alto grau de transformações que podem ocorrer em um curto espaço de tempo. De tal modo, diante dos indicadores já apontados, a TABELA III reúne todas as características analisadas por setor e a mensuração do grau de vulnerabilidade correspondente. Com base na interpolação dos dados colhidos e analisados delimitou-se as áreas que apresentam baixa, média, alta e muito alta vulnerabilidade física à erosão costeira, conforme exposto na fig. 7 .

A análise conjunta dos indicadores indica que a frente litorânea de Aracaju possui as quatro classes de vulnerabilidade: muito alta, alta, média e baixa.

Os setores que apresentam vulnerabilidade muito alta perfazem as áreas contíguas às desembocaduras fluviais contidas na área estudo - praia do Mosqueiro na margem esquerda da desembocadura do rio Vaza-Barris e, praia dos Artistas na margem direita da desembocadura do rio Sergipe. Estas são assim classificadas, por comporem praias

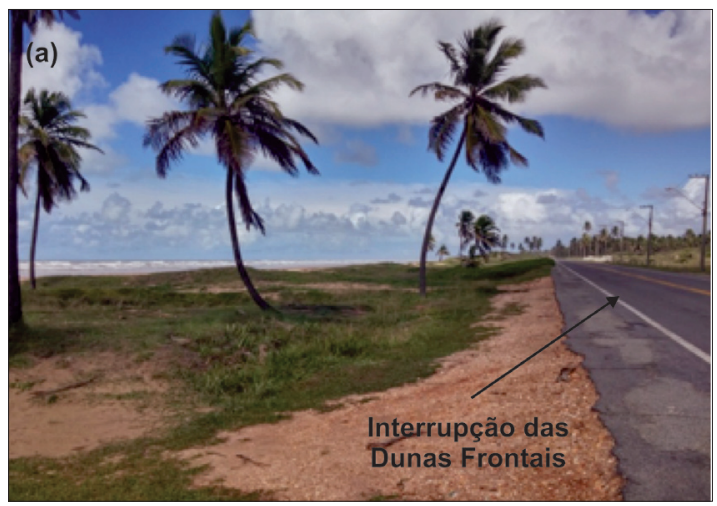

que estão sujeitas diretamente à dinâmica fluviomarinha, o que as tornam extremamente mais vulneráveis, mesmo que estas viessem a apresentar características de estabilidades e/ou indicadores que apontem para alta resistência. Isto é, em casos específicos de desembocaduras é desprezada a análise dos geoindicadores, e considerado apenas a localidade e influência fluviomarinha.

As áreas incluídas na classificação de vulnerabilidade alta estão localizadas majoritariamente nos setores II e III, mais especificamente nas praias dos Náufragos, e em pequenas porções das praias do Refúgio e do Robalo. Nestas localidades foram identificadas pós-praias mais estreitas com vegetação esparsa, e dunas frontais variando entre pequeno e médio porte. Outro indício que fortaleceu essa classificação foi o fato de que estas praias, apesar de atualmente estáveis, já passaram por processos erosivos, e, em função dos indicadores vistos em alguns pontos, a exemplo da transposição do cordão (overwash), que pode indicar tendência futura a ocorrência de erosão.

Neste ponto da discussão merece destaque o fato de que, não obstante a mensuração da vulnerabilidade física à erosão costeira ser realizada com base exclusivamente nas características naturais do ambiente praial, há de se considerar a alteração do referido ambiente pela ação humana que pode o tornar mais vulnerável. Na área em estudo, por exemplo, alguns dos setores que possuem vulnerabilidade alta, assim o são pela baixa resistência que a praia oferece, muito em função da supressão da vegetação e das dunas frontais, seja pela construção dos bares na pós-praia, seja pela presença da rodovia que interrompeu o campo de dunas.

Apenas uma pequena porção do setor II foi inserido no grau de vulnerabilidade médio. Já inserido no grau baixo de vulnerabilidade, encontra-se quase todo o setor I (praia da Aruana e parte da praia da Atalaia). Estas áreas são as que apresentaram maior resistência à erosão costeira, em função da presença de pós-praias largas

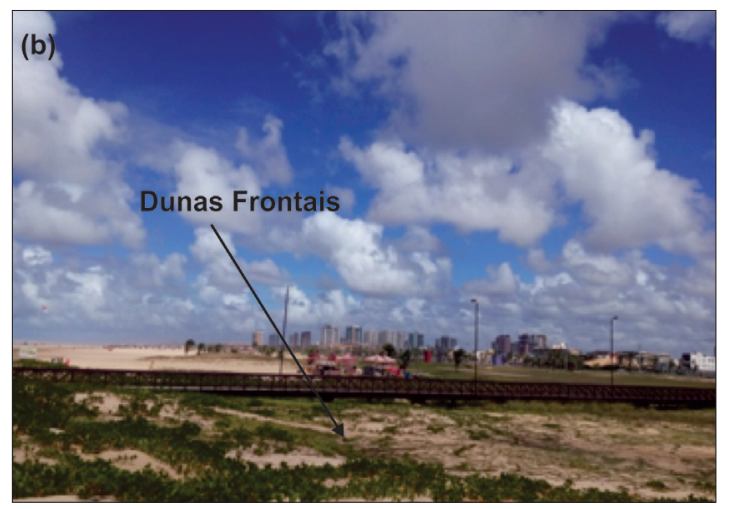

Fig. 5 - Presença das dunas frontais na área de estudo. Em (a): praia do Robalo; Em (b) praia da Atalaia (Fonte: Luana Santos Oliveira Mota, Maio de 2016.

Fig. 5 - Frontal dunes found in the study area. In (a): Robalo Beach; In (b) Atalaia Beach (Source: Luana Santos Oliveira Mota, May 2016). 
e vegetadas, com presença de dunas frontais de médio porte. Em adendo, acrescenta-se o fato de que a análise em curto e médio prazo da variação da linha de costa indica tendência à progradação nestes setores, em que não foram identificados evidências de erosão pretérita.
A mensuração realizada não indicou a presença do grau de vulnerabilidade baixa. Justifica-se este fato pela razão de não ter havido coincidência entre as áreas que apresentaram tendência a progradação em médio e curto prazo com áreas que possuíssem elevado grau de resistência.

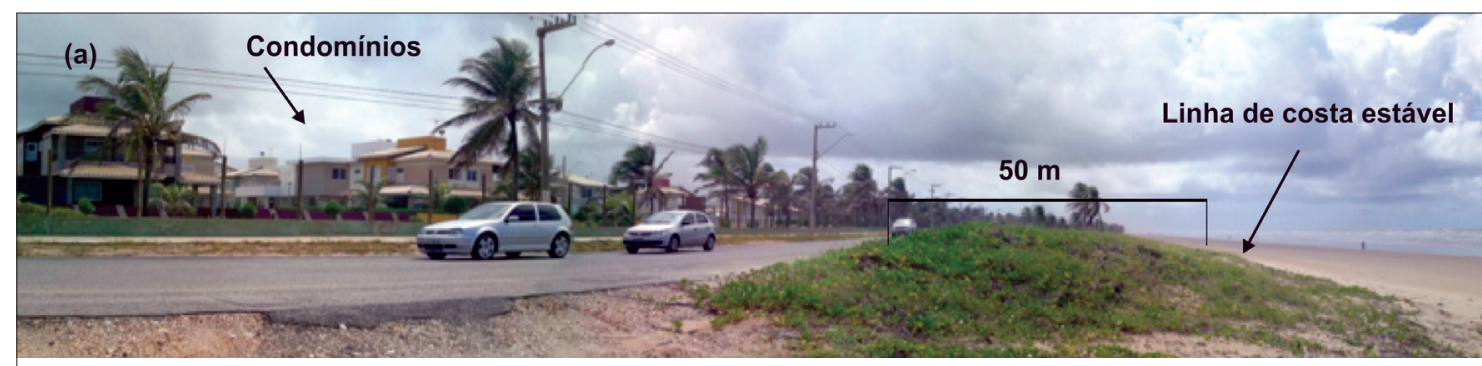

(b)

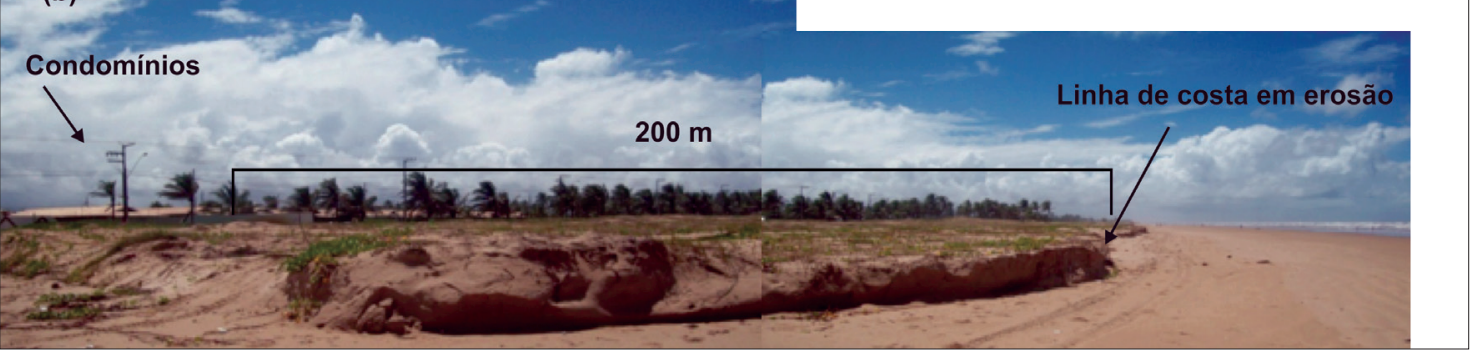

Fig. 6 - Relação entre dunas frontais e erosão costeira. Em (a): menor resistência da praia a processos erosivos - praia do Robalo; Em (b): maior resistência da praia a processos erosivos - praia dos náufragos (Fonte: Luana Santos Oliveira Mota, Maio de 2016).

Fig. 6 - Relationship between frontal dunes and coastal erosion. In (a): beach less resistant to erosion - Robalo beach; In (b): beach more resistant to erosion - Naúfrafos beach (Source: Luana Santos Oliveira Mota, May 2016.

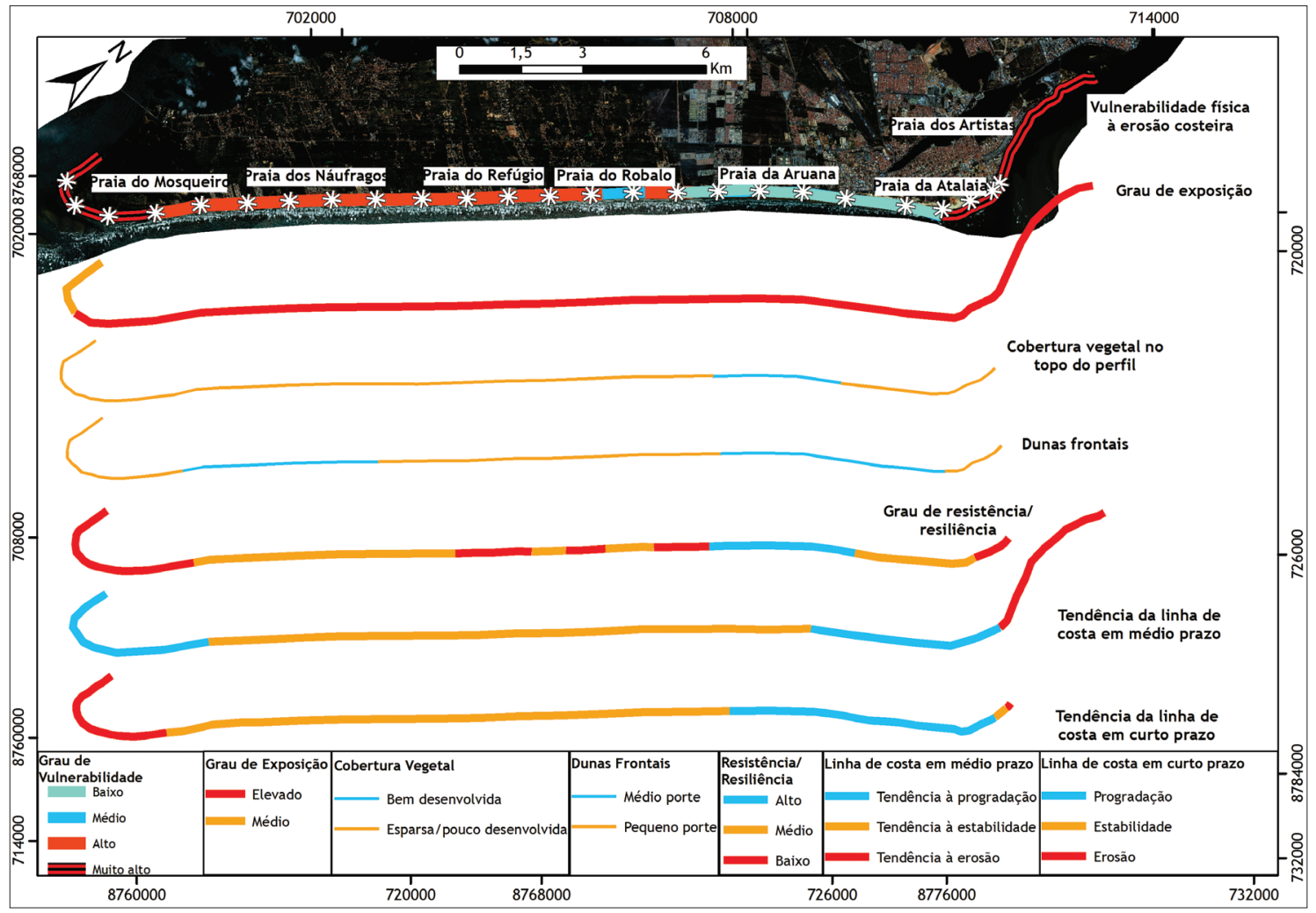

Fig. 7 - Vulnerabilidade física à erosão costeira da frente litorânea de Aracaju/SE.

Fig. 7 - Coastal front of Aracaju, physical vulnerability to coastal erosion. 
TABELA III - Indicadores da vulnerabilidade física à erosão costeira.

TABLe III - Indicators of physical vulnerability to coastal erosion.

\begin{tabular}{|c|c|c|c|c|c|c|c|c|c|c|}
\hline \multirow{2}{*}{$\begin{array}{l}\text { ڤ̆ } \\
\stackrel{0}{0}\end{array}$} & \multirow{2}{*}{ 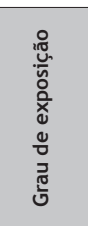 } & \multicolumn{3}{|c|}{ Grau de resistência/resiliência } & \multirow[b]{2}{*}{$\begin{array}{l}\text { Tendência da linha de } \\
\text { costa em médio prazo }\end{array}$} & \multirow{2}{*}{ 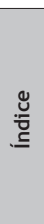 } & \multirow{2}{*}{$\begin{array}{c}\text { Tendência } \\
\text { da linha de } \\
\text { costa em curto } \\
\text { prazo }\end{array}$} & \multirow{2}{*}{ 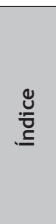 } & \multirow{2}{*}{$\begin{array}{l}\bar{\pi} \\
\stackrel{0}{0} \\
\stackrel{u}{0} \\
.0\end{array}$} & \multirow{2}{*}{ 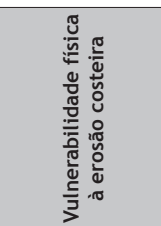 } \\
\hline & & $\begin{array}{l}\text { Cobertura } \\
\text { vegetal no } \\
\text { topo do } \\
\text { perfil }\end{array}$ & Dunas frontais & 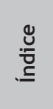 & & & & & & \\
\hline 1 & Médio & $\begin{array}{c}\text { Esparsa } \\
\text { e pouco } \\
\text { desenvolvida }\end{array}$ & $\begin{array}{l}\text { Dunas frontais de } \\
\text { pequeno porte } \\
\text { vegetadas }\end{array}$ & 3 & $\begin{array}{l}\text { Progradação (grandes va- } \\
\text { riações de posicionamen- } \\
\text { to nos últimos } 50 \text { anos) }\end{array}$ & 1 & Erosão & 3 & 2,3 & $\begin{array}{c}\text { Muito elevada } \\
\text { (proximidade da } \\
\text { desembocadura) }\end{array}$ \\
\hline 2 & Médio & $\begin{array}{c}\text { Esparsa } \\
\text { e pouco } \\
\text { desenvolvida }\end{array}$ & $\begin{array}{l}\text { Dunas frontais de } \\
\text { pequeno porte } \\
\text { vegetadas }\end{array}$ & 3 & $\begin{array}{l}\text { Progradação (grandes va- } \\
\text { riações de posicionamen- } \\
\text { to nos últimos } 50 \text { anos) }\end{array}$ & 1 & Erosão & 3 & 2,3 & $\begin{array}{c}\text { Muito elevada } \\
\text { (proximidade da } \\
\text { desembocadura) }\end{array}$ \\
\hline 3 & Elevado & $\begin{array}{c}\text { Esparsa } \\
\text { e pouco } \\
\text { desenvolvida }\end{array}$ & $\begin{array}{l}\text { Dunas frontais de } \\
\text { pequeno porte } \\
\text { vegetadas }\end{array}$ & 3 & $\begin{array}{l}\text { Progradação (grandes va- } \\
\text { riações de posicionamen- } \\
\text { to nos últimos } 50 \text { anos) }\end{array}$ & 1 & Erosão & 3 & 2,3 & $\begin{array}{l}\text { Muito elevada } \\
\text { (proximidade da } \\
\text { desembocadura) }\end{array}$ \\
\hline 4 & Elevado & $\begin{array}{c}\text { Esparsa } \\
\text { e pouco } \\
\text { desenvolvida }\end{array}$ & $\begin{array}{l}\text { Dunas frontais de } \\
\text { pequeno porte } \\
\text { vegetadas }\end{array}$ & 3 & $\begin{array}{l}\text { Progradação (grandes va- } \\
\text { riações de posicionamen- } \\
\text { to nos últimos } 50 \text { anos) }\end{array}$ & 1 & Erosão & 3 & 2,3 & $\begin{array}{l}\text { Muito elevada } \\
\text { (proximidade da } \\
\text { desembocadura) }\end{array}$ \\
\hline 5 & Elevado & $\begin{array}{c}\text { Esparsa } \\
\text { e pouco } \\
\text { desenvolvida } \\
\end{array}$ & $\begin{array}{l}\text { Dunas frontais } \\
\text { de médio porte } \\
\text { vegetadas }\end{array}$ & 2 & $\begin{array}{c}\text { Estabilidade (pequenas } \\
\text { variações ao longo dos } \\
\text { últimos } 50 \text { anos) }\end{array}$ & 2 & $\begin{array}{c}\text { Estabilidade } \\
\text { (com tendência } \\
\text { à erosão) }\end{array}$ & 2 & 2 & Alta \\
\hline 6 & Elevado & $\begin{array}{c}\text { Esparsa } \\
\text { e pouco } \\
\text { desenvolvida }\end{array}$ & $\begin{array}{l}\text { Dunas frontais } \\
\text { de médio porte } \\
\text { vegetadas }\end{array}$ & 2 & $\begin{array}{l}\text { Estabilidade (pequenas } \\
\text { variações ao longo dos } \\
\text { últimos } 50 \text { anos) }\end{array}$ & 2 & $\begin{array}{c}\text { Estabilidade } \\
\text { (com tendência } \\
\text { à erosão) }\end{array}$ & 2,5 & 2,2 & Alta \\
\hline 7 & Elevado & $\begin{array}{c}\text { Esparsa } \\
\text { e pouco } \\
\text { desenvolvida }\end{array}$ & $\begin{array}{l}\text { Dunas frontais } \\
\text { de médio porte } \\
\text { vegetadas }\end{array}$ & 2 & $\begin{array}{c}\text { Estabilidade (pequenas } \\
\text { variações ao longo dos } \\
\text { últimos } 50 \text { anos) }\end{array}$ & 2 & $\begin{array}{l}\text { Estabilidade } \\
\text { (com tendência } \\
\text { à erosão) }\end{array}$ & 2,5 & 2,2 & Alta \\
\hline 8 & Elevado & $\begin{array}{c}\text { Esparsa } \\
\text { e pouco } \\
\text { desenvolvida }\end{array}$ & $\begin{array}{l}\text { Dunas frontais } \\
\text { de médio porte } \\
\text { vegetadas }\end{array}$ & 2 & $\begin{array}{l}\text { Estabilidade (pequenas } \\
\text { variações ao longo dos } \\
\text { últimos } 50 \text { anos) }\end{array}$ & 2 & $\begin{array}{l}\text { Estabilidade } \\
\text { (com tendência } \\
\text { à erosão) }\end{array}$ & 2,5 & 2,2 & Alta \\
\hline 9 & Elevado & $\begin{array}{c}\text { Esparsa } \\
\text { e pouco } \\
\text { desenvolvida }\end{array}$ & $\begin{array}{l}\text { Dunas frontais de } \\
\text { pequeno porte } \\
\text { vegetadas }\end{array}$ & 2 & $\begin{array}{l}\text { Estabilidade (pequenas } \\
\text { variaccões ao longo dos } \\
\text { úttimos } 50 \text { anos) }\end{array}$ & 2 & $\begin{array}{l}\text { Estabilidade } \\
\text { (com tendência } \\
\text { à erosão) }\end{array}$ & 2,5 & 2,2 & Alta \\
\hline 10 & Elevado & $\begin{array}{c}\text { Esparsa } \\
\text { e pouco } \\
\text { desenvolvida }\end{array}$ & $\begin{array}{l}\text { Dunas frontais de } \\
\text { pequeno porte } \\
\text { vegetadas }\end{array}$ & 2 & $\begin{array}{l}\text { Estabilidade (pequenas } \\
\text { variações ao longo dos } \\
\text { últimos } 50 \text { anos) }\end{array}$ & 2 & $\begin{array}{l}\text { Estabilidade } \\
\text { (com tendência } \\
\text { à erosão) }\end{array}$ & 2,5 & 2,2 & Alta \\
\hline 11 & Elevado & $\begin{array}{c}\text { Esparsa } \\
\text { e pouco } \\
\text { desenvolvida }\end{array}$ & $\begin{array}{l}\text { Ausentes/ Dunas } \\
\text { frontais de pequeno } \\
\text { porte vegetadas }\end{array}$ & 2,5 & $\begin{array}{l}\text { Estabilidade (pequenas } \\
\text { variações ao longo dos } \\
\text { úttimos } 50 \text { anos) }\end{array}$ & 2 & Estabilidade & 2 & 2,2 & Alta \\
\hline 12 & Elevado & $\begin{array}{c}\text { Esparsa } \\
\text { e pouco } \\
\text { desenvolvida } \\
\end{array}$ & $\begin{array}{l}\text { Ausentes/Dunas } \\
\text { frontais de } \\
\text { pequeno porte }\end{array}$ & 3 & $\begin{array}{c}\text { Estabilidade (pequenas } \\
\text { variações ao longo dos } \\
\text { últimos } 50 \text { anos) }\end{array}$ & 2 & Estabilidade & 2 & 2 & Alta \\
\hline 13 & Elevado & $\begin{array}{c}\text { Esparsa } \\
\text { e pouco } \\
\text { desenvolvida }\end{array}$ & $\begin{array}{l}\text { Dunas frontais de } \\
\text { pequeno porte }\end{array}$ & 2 & $\begin{array}{l}\text { Estabilidade (pequenas } \\
\text { variações ao longo dos } \\
\text { úttimos } 50 \text { anos) }\end{array}$ & 2 & Estabilidade & 2 & 2 & Alta \\
\hline 14 & Elevado & $\begin{array}{c}\text { Esparsa } \\
\text { e pouco } \\
\text { desenvolvida }\end{array}$ & $\begin{array}{l}\text { Ausentes/Dunas } \\
\text { frontais de } \\
\text { pequeno porte }\end{array}$ & 3 & $\begin{array}{l}\text { Estabilidade (pequenas } \\
\text { variações ao longo dos } \\
\text { últimos } 50 \text { anos) }\end{array}$ & 2 & Estabilidade & 2 & 2,3 & Alta \\
\hline 15 & Elevado & $\begin{array}{c}\text { Esparsa } \\
\text { e pouco } \\
\text { desenvolvida }\end{array}$ & $\begin{array}{l}\text { Dunas frontais } \\
\text { de baixo porte } \\
\text { vegetadas }\end{array}$ & 2 & $\begin{array}{l}\text { Estabilidade (pequenas } \\
\text { variações ao longo dos } \\
\text { últimos } 50 \text { anos) }\end{array}$ & 2 & $\begin{array}{c}\text { Estabilidade } \\
\text { (com tendência } \\
\text { à progradação) }\end{array}$ & 1,5 & 1,8 & Média \\
\hline 16 & Elevado & $\begin{array}{c}\text { Esparsa } \\
\text { e pouco } \\
\text { desenvolvida }\end{array}$ & $\begin{array}{l}\text { Ausentes/Dunas } \\
\text { frontais de } \\
\text { pequeno porte }\end{array}$ & 2,5 & $\begin{array}{l}\text { Estabilidade (pequenas } \\
\text { variações ao longo dos } \\
\text { últimos } 50 \text { anos) }\end{array}$ & 2 & Estabilidade & 2 & 2,2 & Alta \\
\hline 17 & Elevado & $\begin{array}{c}\text { Vegetação } \\
\text { bem } \\
\text { desenvolvida }\end{array}$ & $\begin{array}{l}\text { Dunas frontais } \\
\text { de médio porte } \\
\text { vegetadas }\end{array}$ & 1 & $\begin{array}{l}\text { Estabilidade (pequenas } \\
\text { variações ao longo dos } \\
\text { últimos } 50 \text { anos) }\end{array}$ & 2 & Progradação & 1 & 1,3 & Baixa \\
\hline 18 & Elevado & $\begin{array}{c}\text { Vegetação } \\
\text { bem } \\
\text { desenvolvida }\end{array}$ & $\begin{array}{l}\text { Dunas frontais } \\
\text { de médio porte } \\
\text { vegetadas }\end{array}$ & 1 & $\begin{array}{l}\text { Estabilidade (pequenas } \\
\text { variações ao longo dos } \\
\text { últimos } 50 \text { anos) }\end{array}$ & 2 & Progradação & 1 & 1,3 & Baixa \\
\hline 19 & Elevado & $\begin{array}{l}\text { Vegetação } \\
\text { bem } \\
\text { desenvolvida }\end{array}$ & $\begin{array}{l}\text { Dunas frontais } \\
\text { de médio porte } \\
\text { vegetadas }\end{array}$ & 1 & $\begin{array}{l}\text { Estabilidade (pequenas } \\
\text { variaccões ao longo dos } \\
\text { últimos } 50 \text { anos) }\end{array}$ & 2 & Progradação & 1 & 1,3 & Baixa \\
\hline 20 & Elevado & $\begin{array}{c}\text { Esparsa } \\
\text { e pouco } \\
\text { desenvolvida }\end{array}$ & $\begin{array}{l}\text { Dunas frontais } \\
\text { de médio porte } \\
\text { vegetadas }\end{array}$ & 2 & Progradação & 1 & Progradação & 1 & 1,3 & Baixa \\
\hline 21 & Elevado & $\begin{array}{c}\text { Esparsa } \\
\text { e pouco } \\
\text { desenvolvida }\end{array}$ & $\begin{array}{l}\text { Dunas frontais } \\
\text { de médio porte } \\
\text { vegetadas }\end{array}$ & 2 & Progradação & 1 & Progradação & 1 & 1,3 & Baixa \\
\hline 22 & Elevado & $\begin{array}{c}\text { Esparsa } \\
\text { e pouco } \\
\text { desenvolvida } \\
\end{array}$ & $\begin{array}{c}\text { Dunas frontais } \\
\text { de médio porte } \\
\text { vegetadas }\end{array}$ & 2 & Progradação & 1 & Progradação & 1 & 1,3 & $\begin{array}{c}\text { Muito elevada } \\
\text { (proximidade da } \\
\text { desembocadura) }\end{array}$ \\
\hline 23 & Elevado & $\begin{array}{c}\text { Esparsa } \\
\text { e pouco } \\
\text { desenvolvida }\end{array}$ & $\begin{array}{l}\text { Dunas frontais de } \\
\text { pequeno porte } \\
\text { vegetadas }\end{array}$ & 2 & Progradação & 1 & Progradação & 1 & 1,3 & $\begin{array}{c}\text { Muito elevada } \\
\text { (proximidade da } \\
\text { desembocadura) }\end{array}$ \\
\hline 24 & Elevado & $\begin{array}{c}\text { Esparsa } \\
\text { e pouco } \\
\text { desenvolvida }\end{array}$ & $\begin{array}{l}\text { Ausentes/Dunas } \\
\text { frontais de pequeno } \\
\text { porte vegetadas }\end{array}$ & 2,5 & Erosão & 3 & Estabilidade & 2 & 2,5 & $\begin{array}{l}\text { Muito elevada } \\
\text { (proximidade da } \\
\text { desembocadura) }\end{array}$ \\
\hline 25 & Elevado & $\begin{array}{c}\text { Esparsa } \\
\text { e pouco } \\
\text { desenvolvida }\end{array}$ & Ausentes & 3 & Erosão & 3 & Erosão & 3 & 3 & $\begin{array}{l}\text { Muito elevada } \\
\text { (proximidade da } \\
\text { desembocadura) }\end{array}$ \\
\hline
\end{tabular}


Nível e distribuição da ocupação ao longo da frente litorânea de Aracaju/SE.

A ocupação nas proximidades da linha de costa na área estudada apresenta dois padrões diferenciados. No que concerne aos bairros Coroa do Meio e Atalaia, componentes do Setor I, a ocupação é densa e distribuída em toda a faixa litorânea. Caracterizada por apresentar aparatos turísticos, residências, condomínios, restaurantes e bares ao longo da pós-praia. Destaca-se também a presença de estruturas verticais de mais de 12 andares.

Já nos Setores II e III a ocupação é pontual e distribuída irregularmente ao longo da frente litorânea. Em geral, são observados condomínios de luxo, entremeados por espaços não ocupados e/ou loteados, dispostos internamente à rodovia José Sarney. Dispostos externamente a esta rodovia, são encontrados muitos bares e restaurantes sobre a pós-praia. Dentro do Setor III está localizada a única área sem ocupação da frente litorânea do município, nas proximidades da desembocadura do rio Vaza-Barris, padrão completamente oposto às margens da desembocadura do rio Sergipe.

Para analisar o nível de ocupação em relação à linha de costa na área, foi considerada a distribuição da ocupação perpendicularmente (primeiro $1 \mathrm{~km}$ da costa) e paralelamente à linha de costa (densidade). Foram utilizados os seguintes parâmetros: de 0-35\% a ocupação é considerada baixa, de 35\%-70\% o nível é considerado médio, e acima de $70 \%$ a ocupação é elevada.

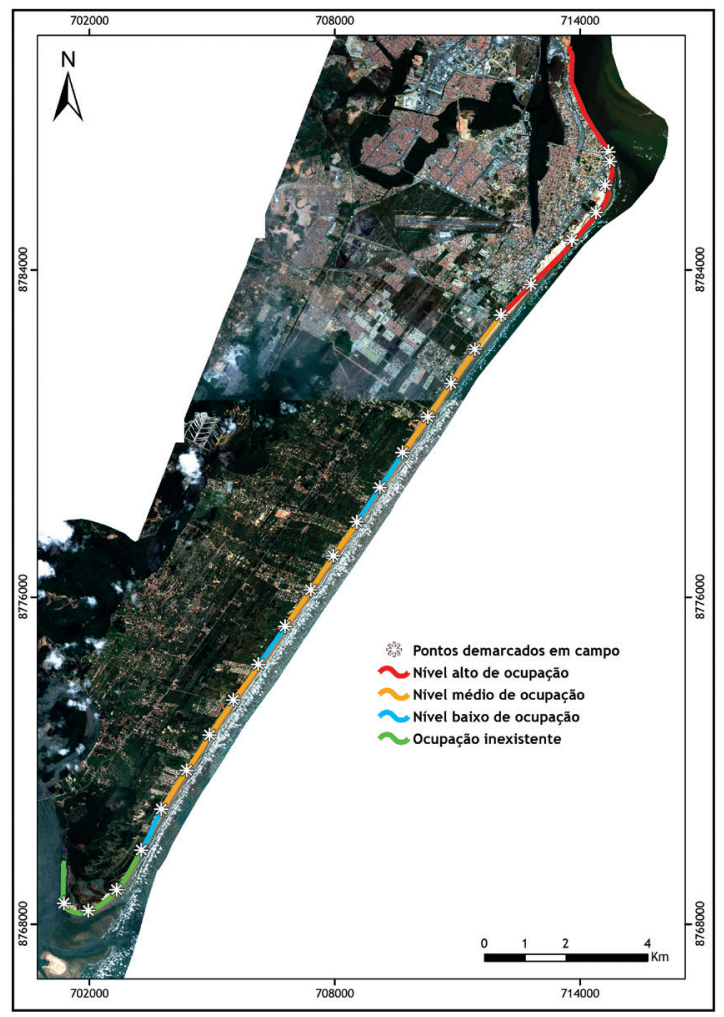

Fig. 8 - Nível de Ocupação da frente litorânea de Aracaju/SE. Fig. 8 - Occupancy level of the coastal front of Aracaju/SE.
Com base nessa distribuição do nível de ocupação e sua distância em relação à linha de costa, calculou-se os índices de ocupação para os diferentes setores (fig. 8).

Avaliação dos riscos associados à ocupação nas proximidades da linha de costa

A partir dos valores indicados para a variável da vulnerabilidade física à erosão costeira e para a variável do nível e distribuição da ocupação calcularam-se os índices de riscos para os setores delimitados (TABELA IV).

Os resultados obtidos indicaram a preponderância dos níveis de risco variando entre médio e alto (fig. 9). Esta tendência é justificada pela conjunção de setores com medianos e elevados índices de ocupação a áreas de elevada vulnerabilidade física à erosão costeira.

Como o risco está diretamente atrelado a existência de ocupação, áreas em que esta é inexistente o risco também será, mesmo que os condicionantes naturais indiquem elevada vulnerabilidade natural. Para o caso da área de estudo, não obstante as áreas adjacentes à desembocadura do rio Vaza-Barris não apresentarem nenhum tipo de ocupação fixa, existe limitada infraestrutura urbana (rodovia e redes elétricas). Para além deste fato, há de se considerar que este setor da costa aracajuana constitui-se como de elevada especulação imobiliária, tendo em vista os atrativos naturais intrínsecos ao ambiente costeiro. Em razão

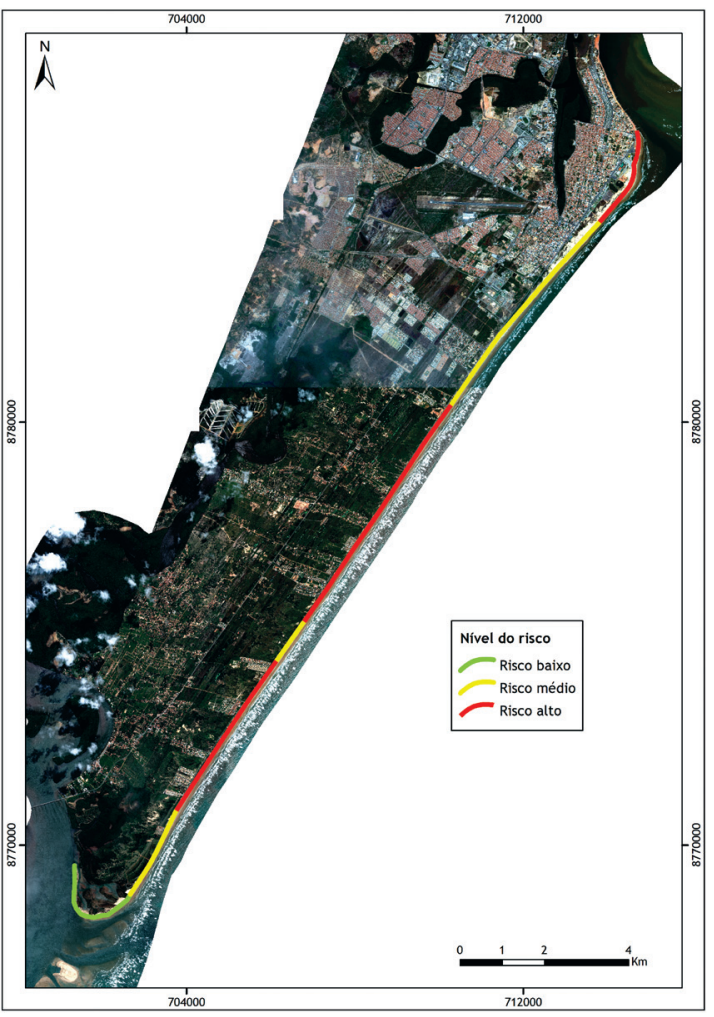

Fig. 9 - Avaliação do risco para a frente litorânea de Aracaju/SE.

Fig. 9 - Evaluation risk for the coastal front of Aracaju/SE. 
TABELA IV - Riscos associados à ocupação nas proximidades da linha de costa.

$T_{A B L E} I V$ - Risks associated to occupation near the coastline.

\begin{tabular}{|c|c|c|c|c|c|c|c|}
\hline $\begin{array}{l}\text { Õ } \\
\stackrel{2}{0}\end{array}$ & $\begin{array}{c}\text { Índice da } \\
\text { vulnerabilidade } \\
\text { à erosão costeira }\end{array}$ & $\begin{array}{l}\text { Índice do nível } \\
\text { de ocupação }\end{array}$ & Nível do Risco & $\begin{array}{l}\tilde{s} \\
\stackrel{0}{0} \\
0\end{array}$ & $\begin{array}{c}\text { Índice da } \\
\text { vulnerabilidade } \\
\text { à erosão costeira }\end{array}$ & $\begin{array}{l}\text { Índice do nível de } \\
\text { ocupação }\end{array}$ & Nivel do Risco \\
\hline 1 & 2,3 & 0 & 1,1 (Baixo/Potencial) & 14 & 2,3 & 1 & 1,6 (Médio) \\
\hline 2 & 2,3 & 0 & 1,1 (Baixo/Potencial) & 15 & 1,8 & 1 & 1,4 (Médio) \\
\hline 3 & 2,3 & 0 & 1,1 (Baixo/Potencial) & 16 & 2,2 & 2 & 2,1 (Alto) \\
\hline 4 & 2,3 & 1 & 1,6 (Médio) & 17 & 1,3 & 2 & 1,7 (Médio) \\
\hline 5 & 2 & 1 & 1,5 (Médio) & 18 & 1,3 & 2 & 1,7 (Médio) \\
\hline 6 & 2,2 & 2 & 2,1 (Alto) & 19 & 1,3 & 2 & 1,7 (Médio) \\
\hline 7 & 2,2 & 2 & 2,1 (Alto) & 20 & 1,3 & 3 & 2,1 (Alto) \\
\hline 8 & 2,2 & 2 & 2,1 (Alto) & 21 & 1,3 & 3 & 2,1 (Alto) \\
\hline 9 & 2,2 & 2 & 2,1 (Alto) & 22 & 1,3 & 3 & 2,1 (Alto) \\
\hline 10 & 2,2 & 1 & 1,6 (Médio) & 23 & 1,3 & 3 & 2,1 (Alto) \\
\hline 11 & 2,2 & 2 & 2,1 (Alto) & 24 & 2,5 & 3 & 2,8 (Alto) \\
\hline 12 & 2 & 2 & 2 (Médio) & 25 & 3 & 3 & 3 (Alto) \\
\hline 13 & 2 & 2 & 2 (Médio) & & & & \\
\hline
\end{tabular}

destes fatos, optou-se por classificar esta porção da costa como de baixo risco/risco em potencial.

A valorização do espaço costeiro configura-se como um dos grandes responsáveis pela potencialização dos riscos nestes ambientes. Esta valorização é tida por C. Vitte (2003) como o ato de atribuir um valor a um elemento da natureza, tornando-o um bem a ser consumido. Um exemplo claro desta circunstância é o apelo paisagístico atrelado às praias, os quais resultam em uma valorização elevada dos terrenos defronte ao mar, e, consequentemente, no aumento da pressão antropogênica nas áreas próximas à linha de costa. Para o caso do munícipio de Aracaju, este apelo tem aumentado sobremaneira desde a década de 1980, atingindo o ápice na presente década, o que tem resultado no acréscimo exponencial de área ocupada nas adjacências da frente litorânea e consequente potencialização e aumento das áreas de risco.

Políticas de manejo específicas para as áreas próximas à linha de costa.

Com base na análise dos geoindicadores de modificação da linha de costa em curto prazo, da variação do posicionamento da linha de costa a médio prazo e do nível de ocupação nas proximidades da linha de costa na frente litorânea de Aracaju, foi possível determinaras as áreas que necessitam de gerenciamento costeiro preventivo ou corretivo, com base na metodologia de S. Esteves (2003) e F. Lins-de-Barros (2005) no que se refere à determinação das áreas críticas, áreas de ação prioritária, áreas latentes e áreas naturais (fig. 10).

As áreas críticas são as que necessitam de gerenciamento costeiro corretivo, devido à destruição de estruturas fixas pela erosão costeira e ao alto nível de concentração populacional. Nesta classe, enquadra-se a porção atingida por um processo erosivo severo pretérito que destruiu parte da rodovia José Sarney, na margem esquerda da desembocadura do rio Vaza-Barris (praia do Mosqueiro), assim como a margem direita da desembocadura do rio Sergipe (praia dos Artistas). Essas áreas foram assim classificadas por necessitarem de medidas corretivas, em função da destruição de estruturas fixas

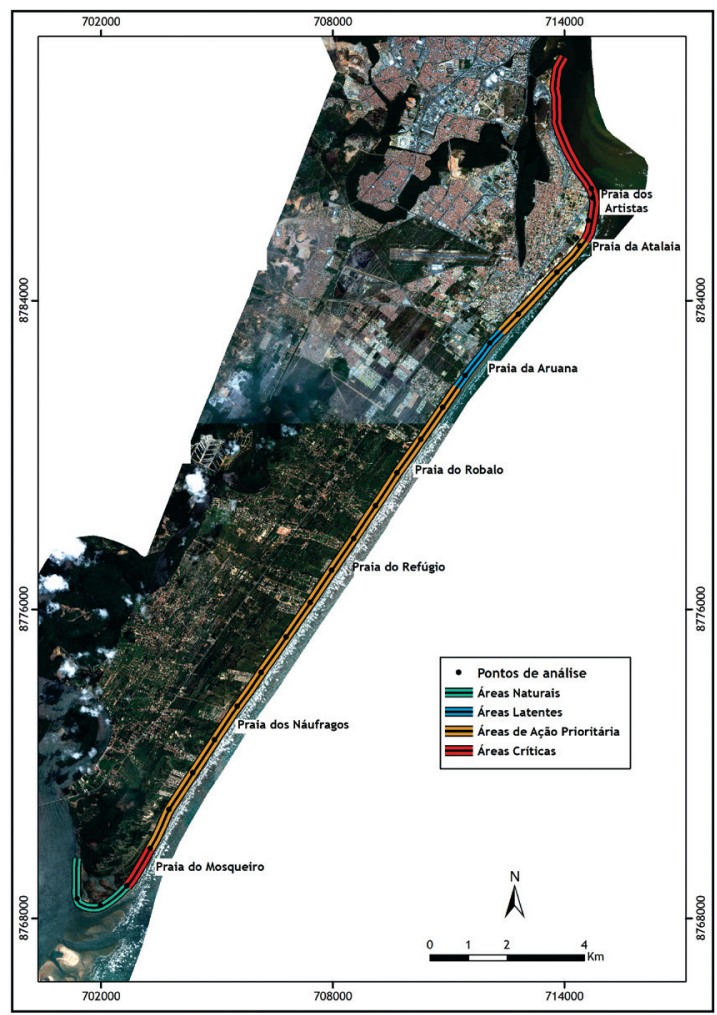

Fig. 10 - Áreas de manejo especial para frente litorânea de Aracaju/SE.

Fig. 10 - Special management areas for coastal front of Aracaju/SE. 
pela erosão. Ressalta-se que, a margem esquerda da desembocadura do rio Vaza-Barris, não condiz com a descrição realizada para áreas críticas no que concerne ao nível de ocupação, mas por necessitar de ações corretivas urgentes, optou-se por incluí-la nesta classe. Já no que se refere à margem direita da desembocadura do rio Sergipe, há elevado nível de ocupação associado a eventos erosivos pretéritos e atuais. Destaca-se que neste setor já foram construídos molhes no intuito de conter o processo erosivo.

As áreas de ação prioritária são as áreas que estão sob pressão antrópica constante, com nível de ocupação baixo ou médio, tendendo ao aumento, apresentando tendência à erosão ou estabilidade da linha de costa. A maior parte da área foi classificada dentro dessa categoria, em que se incluem parte da praia de Atalaia, praia do Robalo, praia do Refúgio e praia dos Náufragos. Como já foi discutido anteriormente, estas praias possuem níveis de ocupação bem diferenciados, assim como tendências distintas da linha de costa. Apesar das referidas diferenças, elas pertencem a mesma classe em função da confluência de algumas características.

Parte da praia de Atalaia, por exemplo, possui tendência à progradação somado aos maiores índices de ocupação visualizados na frente litorânea de Aracaju. Esta não pode ser classificada como crítica, pois não possui estruturas fixas destruídas pela erosão, assim como, não pode ser considerada latente por possuir elevados índices de interferência antrópica. De tal modo, apesar de não estar sujeita a eventos erosivos, no que concerne ao planejamento, merece atenção especial, e deve ser uma área de ação prioritária.

Já para as praias do Robalo, Refúgio e Náufragos, os índices de ocupação variam entre baixo e médio, somado a tendência à estabilidade/erosão da linha de costa. Estes setores devem ser tratados com cautela, uma vez que se caracterizam pela intensa especulação imobiliária, que aponta para o aumento considerável da ocupação nos próximos anos.

As áreas latentes caracterizam-se pela baixa pressão antrópica, com preservação do sistema dunar e praias com tendências a progradação. 0 setor analisado que se inclui nesta classificação é parte da praia de Aruana, uma vez que a pressão antrópica nas proximidades da linha de costa é baixa e há tendência geral à progradação. Elucida-se, que não obstante pertencer a referida classe há necessidade de gerenciamento preventivo, em função do aumento populacional da frente litorânea.

Por fim, têm-se as áreas naturais, as quais se encontram sem ocupação, com as características naturais inteiramente preservadas. A porção mais ao sul, nas adjacências do rio Vaza-Barris, foi assim classificada, uma vez que a ocupação é inexistente.
Destarte, observa-se para a área de estudo a necessidade de medidas preventivas e corretivas no que tange ao gerenciamento costeiro. Identificou-se que a frente litorânea do município ainda não é inteiramente ocupada, em que se constata a possibilidade da aplicação de medidas preventivas, com base na adoção de políticas urbano-ambientais que levem em consideração a dinâmica costeira. A classificação mencionada pode ser utilizada como mecanismo a fim de evitar futuros prejuízos advindos da ocupação irregular deste ambiente, como já observados em dois setores da costa Aracaju.

\section{Conclusões}

A delimitação das áreas de risco para frente litorânea do município de Aracaju/SE foi realizada tendo por base os indicadores de vulnerabilidade física à erosão costeira e o nível/densidade da ocupação.

A vulnerabilidade foi mensurada a partir da análise integrada de parâmetros de médio e curto prazo. Como indicador de médio prazo foi considerado a variação da linha de costa para os últimos 50 anos, o qual apontou para tendências distintas ao longo da costa aracajuana. Já os indicadores de análise em curto prazo, envolvem o grau de resistência e resiliência da praia (dunas frontais e cobertura vegetal no topo do perfil), grau de exposição e geoindicadores de modificação da linha de costa. A mensuração da vulnerabilidade foi obtida pelo cruzamento dos dados colhidos e analisados, em que se verificou a existência das quatro classes de vulnerabilidade física à erosão costeira: vulnerabilidade muito alta - atribuída às margens das desembocaduras fluviais; vulnerabilidade alta - detectada majoritariamente no setor II, na praia dos Náufragos, e em parte das praias do Robalo e do Refúgio e; vulnerabilidade média - pequeno setor da praia do Robalo; vulnerabilidade baixa - predominante no setor I, na praia da Aruana e parte da praia da Atalaia. Em adendo a análise da vulnerabilidade, realizou-se a caracterização da frente litorânea do município em relação ao nível e densidade da ocupação, em que se constatou a presença de níveis elevados de ocupação, perpassando por áreas de ocupação dispersa, chegando até setores sem nenhum tipo de ocupação fixa.

Aanálise síncrona entre os diferentes graus de vulnerabilidade obtidos e os distintos níveis de ocupação, permitiu a delimitação das áreas de risco, em que se observou a preponderância do grau de risco variando entre médio e alto. Somado a esta delimitação, a costa foi classificada em quatro áreas de manejo especiais: áreas naturais, presente apenas nas margens da desembocadura do rio Vaza-Barris; áreas latentes, circunscrita à praia de Aruana; áreas de ação prioritária que perfazem a maior parte da área de estudo e; áreas críticas localizadas nas adjacências das desembocaduras do rio Sergipe e Vaza-Barris. Tal classificação visa a auxiliar o planejamento ambiental partindo de ações 
do gerenciamento costeiro, uma vez que é definido medidas corretivas, para áreas críticas, e medidas preventivas para as áreas naturais, latentes e de ação prioritária.

A análise prognóstica da frente litorânea de Aracaju indica uma tendência clara ao acréscimo da ocupação, em função da elevada especulação imobiliária para os terrenos que margeiam as praias. É diante deste cenário, de conjunção entre elevado uso e ocupação do solo e elevada variabilidade e dinâmica natural, que a avaliação do risco é fundamental, não obstante ter sido pouco considerada para o planejamento da ocupação da referida cidade. Por tal razão, reforça-se a necessidade de medidas preventivas, a exemplo do planejamento para quaisquer tipos de intervenção antrópica na frente litorânea, a fim de evitar possíveis prejuízos socioeconômicos, advindos de conflito entre dinâmica natural e mau uso do ambiente costeiro. Tais medidas podem ser tomadas tendo por respaldo a classificação das praias em função da avaliação do risco, uma vez que esta se destina à análise pormenorizada em curto e médio prazo, fornecendo dados que possibilitam o ordenamento da ocupação tendo em vista à dinâmica do natural da zona costeira.

\section{Referências Bibliográficas}

Angulo, Rodolfo José (1993). A Ocupação Urbana do Litoral Paranaense e as Variações da Linha de Costa. Boletim Paranaense de Geociências. Curitiba, p.73-81.

Bird, C. F. Eric (2008). Coastal Geomorphology: an introduction. Wiley. Austrália, 436 p.

Bittencourt, C. S. P. Abílio, Lessa, C. Guilherme, Dominguez, M. L. José, Martin, Louis, Bôas, S. V. Geraldo, Farias, F. Félix (2001). High And Low Frequency Erosive and Constructive Cycles in Estuarine Beaches: An Example From Garcez point, Bahia/Brazil. An. Acad. Bras. Cienc. Rio de Janeiro, n. ${ }^{\circ}$ 4, p.599-610.

Bush, David, Neal, J. Willian, Young, S. Robert, Pilkey, H. Orrin (1999). Utilization of geoindicators for rapid assessment of coastal-hazard risk and mitigation. Ocean \& Coastal Management, n. ${ }^{\circ}$ 42. p.647-670.

Cooper, J. Andrew. G (2002). The role of extreme floods in estuary-coastal behaviour: contrasts bewtween river-and tide dominated microtidal estuaries. Sedimentary Geology. p. 123-137, 2002.

Davis, A. Richard e Fitzgerald, M. Duncan (2004). Beach and Coasts. Blackwell Science Ltd. Austrália, 432 p.

DHN - DIRETORIA DE HIDROGRAFIA E NAVEGAÇÃO DO BRASIL (2016). Tábuas de maré. Marinha do Brasil. http://www.dhn.br

Dolan, H. Anne, Walker, J. Ian (2004). Understanding vulnerability of coastal communities to climate change related risks. Journal of Coastal Research. n. ${ }^{\circ} 39$, p. 1317-1324.
Esteves, S. L (2003). Estado-da-arte dos métodos de mapeamento da linha de costa. Instituto de Geociências. Porto Alegre, $55 \mathrm{p}$.

Fitzgerald, M. Duncan (1982). Sediment Bypassing at Mixed Energy Tidal Inlets. Coastal Engineering. Boston, p. 1094-1118.

Lins-de-Barros, M. Flávia (2005). Risco, vulnerabilidade física à erosão costeira e impactos socioeconômicos na orla urbanizada do munícipio de Maricá, Rio de Janeiro. Revista Brasileira de Geomorfologia. $n^{\circ} 2$, p. 83-90.

MMA - MINISTÉRIO DO MEIO AMBIENTE (2002). Projeto Orla: fundamentos para gestão integrada. Brasília, $36 \mathrm{p}$.

Morton, A. Robert, Pilkey, H. Orrin Jr., Pilkey, H. Orrin Sr., Neal, J. William (1983). Living with the Texas shore. Duke University Press, Durham, North Carolina.

Muehe, Dieter e Klum-Oliveira, L (2014). Deslocamento da linha de costa versus mobilidade praial. Quaternary and Environmental Geosciences. Curitiba, n. ${ }^{\circ}$ 5, p. 121-124.

Oliveira, B. Marta (2003). Caracterização integrada da linha de costa do Estado de Sergipe - Brasil, IGEO, Salvador, 150 p.

Pianca, Cássia, Mazzine, L.F. Pierro, Siegle, Eduardo (2010). Brazilian Offshore Wave Climate Based On Nww3 Reanalysis. Brazilian Journal of Oceanography, São Paulo, n. ${ }^{\circ}$ 58, p. 53-70.

Psuty, P. Norbert (2004). The coastal foredune: a morphological basis for regional coastal dune development. In: Psuty, P. Norbert e Martínez, M. Luisa. Coastal Dunes: Ecology and Coservation. Springer-Verlag Berlin Heidelberg, p.12-17.

Silva, R. Iracema, Bittencourt, C.S.P. Abílio, Dominguez, L. José Maria, Mello e Silva, B. Sylvio (2007). Potencial de Danos Econômicos Face à Erosão Costeira, Relativo às Praias da Costa do Descobrimento - Litoral Sul do Estado da Bahia. Revista Pesquisa em Geociências. p. 35-44.

Souza, G. Célia Regina e Suguio, Kenitiro (2003). The coastal erosion risk zoning and the São Paulo state plan for coastal management. Journal of Costal Research. Itajaí, n. ${ }^{\circ}$ 35, p. 530-547.

Stive,J. F. Marcel, Aarninkhof, G.J. Stefan, Hamm, Luc, Hanson, Hans., Larson, Magnus, Wijnberg, M. Kathelijne, Nicholls, J. Robert, Capobianco, Michele (2002). Variability of shore and shoreline evolution, Coastal Engineering, n. ${ }^{\circ} 47$, p. 211-235.

Vitte, Antônio Carlos (2003). O litoral brasileiro: a valorização do espaço e os riscos socioambientais. Territorium. Coimbra, $\mathrm{n}^{\circ}$ 10, p. 61-67. Disponível em: http://www.uc.pt/fluc/nicif/riscos/Documentacao/ Territorium/T10_artg/T10_artg04.pdf

Wright, L. D. (1977). Sediment transport and deposition at river mouths: A synthesis. Society America Bulletin. n. ${ }^{\circ}$ 6, p.857-868. 